\title{
EFFECT OF SULPHUR ADDITIVES ON THE CHEMICAL COMPOSITION OF COMPOST
}

\author{
E. A. Abou Hussien, M. N. E. Faiyad, W. M. A. Nada and M. Kh. E. Elgezery \\ Soil Sci. Dept., Fac. of Agric. Menoufia Univ. Shebin El-Kom, Egypt
}

Received: Sep. 26,2016

Accepted: Oct. 20,2016

\begin{abstract}
This study was carried out at green house of Soil Science Department, Faculty of Agriculture, Menoufia University, Shebin El-Kom, Egypt to study the effect of different sulphur (S) additives on the chemical properties and the content of available macro-and micronutrients in the compost produced from maize stalks at different composting periods. Four piles of fine maize stalks and farmyard manure with mixed ratio of 65:35 by weight were tested. These piles were treated with $S$ at rates of 0,1,2 and $3 \%$ based on the dry weight. The piles were moisted at $60 \%$ WHC of the composted organic materials and aerated every 15 days. Samples of each pile were taken at 0, 20, 40 and 60 days of composting and analyzed for their chemical properties and the content of available macro and micronutrients.

The obtained data show that, increasing of both added $S$ and composting period induced a decrease in organic matter (OM) content and $\mathrm{pH}$ in the compost, but the content of total $\mathrm{N}(\%)$ and $E C$ were increased. So, $C / N$ ratios become most narrow in the treatment of $3 \% S$ at 60 days of composting. In addition, the produced compost content of available macronutrients $(N$, $\mathrm{P}, \mathrm{K}, \mathrm{Ca}, \mathrm{Mg}$ and $\mathrm{S}$ ) and micronutrients ( $\mathrm{Fe}, \mathrm{Zn}, \mathrm{Mn}$ and $\mathrm{Cu}$ ) were augmented with the increase of added $S$ and composting period. These findings mean that, $S$ additives to the composted organic materials improved the compost properties and quality.
\end{abstract}

Key words: Compost, Sulphur, Maize stalks, Composting period and Compost properties.

\section{INTRODUCTION}

Composting transforms organic waste into a more uniform and biologically stable product that can act as slow release source of plant nutrients. Compost is an economic and safe way for treatment of organic waste and has high concentrations of organic matter and available nutrients (Verma, 2013 and Razikordmahalleh, 2014). The application of organic wastes with a high organic matter content, such as fresh and composted urban wastes, shredded and composted plant materials derived from municipal landscape (Walker and Dawson, 2003), and cotton gin compost and poultry manure (Tejada et al., 2006) to semiarid soils has become a common environmental practice for soil restoration, maintaining soil organic matter, reclaiming degraded soils, and supplying plant nutrients. Marwa (2007) found that, the organic matter in soil play an important role through building up soil aggregates and enhancing proper soil physical and chemical properties. The application of organic matter to examined sand soil improved its physical as well as chemical and fertility properties.

Sulphur is recognized as the fourth major plant nutrient after nitrogen, phosphorus and potassium in crop productivity. It is a consistent of sulphur containing amino acids (Cysteine and methionine) which are building blocks for essential protein in the plant. Moreover, it is essential for good vegetative growth and bulb development in plant and it has a strong influence on potato flower and pungency through involvement in the volatile S-compounds (Anwar et al., 2001; Havlin et al., 2004 and Forney et al., 2010). Sulphur transformations on a perunit-weight basis are often greater in organic horizons because of the concentration of microbial activity, and transformation rates also tend to be greater in organic horizons (Strickland et al. 1987). However, total 
transformations actually may be greater in lower mineral horizons due to the greater mass of soil present (Strickland et al. 1987 and Schindler et al. 1986).

Organic matter decomposition rates vary with chemical makeup and complexities, and whether net $S$ mineralization occurs depends upon the $S$ supply and microbial demand. If more $S$ is available to the system than needed to meet $S$ requirements of sulphur-using microorganisms, mineralization will occur. If less $S$ is available than needed, all $S$ entering the system will become immobilized because microbial needs must be satisfied first. Consequently, in systems where $S$ is limiting, a larger percentage of total $S$ is found in microbial biomass than in systems where $S$ is not limiting (Strick and Nakas, 1984).

This study represented one trail must be carried to improve and increase the compost quality. This trail is summarized in treated the composted organic materials by elemental sulphur (S) during composting process. The effect of different $S$ additives on the compost chemical properties and its contents of available macro- and micronutrients were determined.

\section{MATERIALS AND METHODS}

The study was carried out at green house of Soil Sci. Dept., Fac. of Agric. Menoufia Univ. Shebin El-Kom, Egypt to study the effect of $S$ additives and composting period on the chemical properties of the composted organic materials.

\section{Composted organic materials}

The used two organic wastes are: -

a) Maize stalks (MS). Samples of MS were collected, spreaded in the open-air conditions for dryness. Then chopped into $2-4 \mathrm{~cm}$ segment using rushing machine.

b) Farmyard manure (FYM). Air dried FYM was obtained from the Animal Breeding Farm, Faculty of Agriculture, Menoufia University, Shebin El-Kom

\section{Elemental sulphur (S)}

This material which supplied by El-Help company, Egypt. $99 \%$ of purity sulphur and $\mathrm{pH}(1: 5$ suspension $)=6.42$.

\section{Composting process}

Each type of the used organic wastes was cut to small pieces $(2-4 \mathrm{~cm})$ and arranged in 6 equal height layers proliferate good conditions for aeration and decomposition processes which was used four piles (A, B, C and D) were made from mixture of chopped maize stalks and FYM as organic activators at ratio of $65: 35$ by weight.

- Pile "A" without sulphur additives (CSO). - Pile "B" mixed with $1 \%$ sulphur (CS1).

- Pile "C" mixed with $2 \%$ sulphur (CS2).

Pile "D" mixed with $3 \%$ sulphur (CS3).

The compost was prepared in polyethylene pots of $50 \mathrm{~cm}$ diameters, and $70 \mathrm{~cm}$ depth, Each pot contained about 20 $\mathrm{kg}$ of air dried mixture maize stalks and FYM. An activating mixture containing about $3.2 \mathrm{~g} \mathrm{Ca}\left(\mathrm{H}_{2} \mathrm{PO}_{4}\right), 10 \mathrm{~g} \mathrm{CaCO}_{3} 0.32 \mathrm{~g}$ urea and $100 \mathrm{~m} / \mathrm{l}$ of fresh fertile soil-water suspension (1:5) was added. Each pile was properly moistened to reach about (50-60\%) of its water holding capacity and left to decompose until 60 days. The piles were turned upside down every 15 days starting from the top and sides into the center to enhance the aerobic decay process. Additional water was sprayed during the turning process to keep moisture content of each pile at almost $60 \%$ of water holding capacity. The organic wastes were satisfactorily decomposed by this method after 60 days (Aiad, 2010). Representative sample of heaps were manually taken after $0,20,40$ and 60 days. These samples air dried ground and analyzed for chemical properties $(\mathrm{pH}, \mathrm{EC}$ and its content of $\mathrm{OM}$ and its Total- $\mathrm{N}$ ) and the content of available macronutrients ( $\mathrm{N}, \mathrm{P}, \mathrm{K}, \mathrm{Ca}, \mathrm{Mg}$ and $\mathrm{S}$ ) and micronutrients (Fe, $\mathrm{Zn}, \quad \mathrm{Mn}$ and $\mathrm{Cu}$ ) according to the methods described by Cottenie et al. (1982) and Page et al. (1982). 


\section{RESULTS AND DISCUSSION}

- Effect of Sulphur Additives and Composting Period on Compost Properties.

\section{- Compost pH}

The presented data in Table (1) reveal the $\mathrm{pH}$ value of maize stalk compost treated by different additives of elemental sulphur "S" and its relative change "RC" (\%) at different composting periods "CP". At the same rate of sulphur additives, compost $\mathrm{pH}$ was decreased with increasing the CP; All $\mathrm{RC}$ values (\%) of $\mathrm{pH}$ in relation with $\mathrm{CP}$ were negative. This finding is in harmony with that obtained by Aiad (2010) who mentioned that, the $\mathrm{pH}$ dropped from 8.15 to
7.63 after $15^{\text {th }}$ days of composting. Because of $\mathrm{H}^{+}$produced by nitrification and organic neutralization. In, this respect $\mathrm{Gu}$ et al. (2011) obtained a similar result with the compost produced from different organic materials.

Regarding to the data of compost $\mathrm{pH}$ in relation with $\mathrm{S}$ additives, the data in Table (1) display that, $\mathrm{pH}$ value of compost decreased with the increase of added $S$. This decrease effect of $S$ additives on compost $\mathrm{pH}$ may be ascribed to oxidation of elemental $\mathrm{S}$ to solve in the moisture content and forming $\mathrm{H}_{2} \mathrm{SO}_{4}$ that resulted in diminishing compost $\mathrm{pH}$.

Table (1): Effect of sulphur " $S$ " additives and composting period "CP" (day) on compost $\mathrm{pH}, \mathrm{EC}\left(\mathrm{dSm}^{-1}\right)$ and organic matter content (OM) and their relative changes (RC $\%)$ in relation with sulphur additives.

\begin{tabular}{|c|c|c|c|c|c|c|c|c|c|c|}
\hline \multirow{3}{*}{$\begin{array}{l}\text { Treatm } \\
\text { ent of } \\
\text { sulphur }\end{array}$} & \multicolumn{10}{|c|}{ Composting period " CP" (day) } \\
\hline & \multicolumn{2}{|c|}{0} & \multicolumn{2}{|c|}{20} & \multicolumn{2}{|c|}{40} & \multicolumn{2}{|c|}{60} & \multicolumn{2}{|c|}{ Mean } \\
\hline & Value & $\mathrm{RC} \%$ & Value & $\mathrm{RC} \%$ & Value & $\mathrm{RC} \%$ & Value & $\mathrm{RC} \%$ & Value & $\mathrm{RC} \%$ \\
\hline & \multicolumn{10}{|c|}{ pH 1:10 (compost : water) susp. } \\
\hline CSO & 7.95 & 0 & 7.75 & 0 & 7.33 & 0 & 6.88 & 0 & - & - \\
\hline CS1 & 7.87 & -1.01 & 7.69 & -0.84 & 7.35 & 0.27 & 6.88 & -0.07 & - & - \\
\hline CS2 & 7.78 & -2.14 & 7.58 & -2.26 & 7.30 & -0.34 & 6.78 & -1.45 & - & - \\
\hline CS3 & 7.78 & -2.14 & 7.49 & -3.42 & 7.28 & -0.68 & 6.64 & -3.49 & - & - \\
\hline Mean & - & & - & & - & & - & & - & \\
\hline & \multicolumn{10}{|c|}{ EC 1:20 (compost : water) extract $\left(\mathrm{dSm}^{-1}\right)$} \\
\hline CSO & 1.58 & 0 & 1.68 & 0 & 1.85 & 0 & 2.24 & 0 & 1.84 & 0 \\
\hline CS1 & 1.62 & 2.53 & 1.75 & 4.17 & 1.96 & 5.95 & 2.54 & 13.39 & 1.97 & 7.07 \\
\hline CS2 & 1.65 & 4.43 & 1.80 & 7.14 & 2.15 & 16.22 & 2.63 & 17.41 & 2.06 & 11.97 \\
\hline CS3 & 1.69 & 6.96 & 1.97 & 8.33 & 2.30 & 24.32 & 2.74 & 22.32 & 2.17 & 18.10 \\
\hline Mean & 1.63 & & 1.79 & & 2.06 & & 2.54 & & 2.01 & \\
\hline & \multicolumn{10}{|c|}{ OM (\%) } \\
\hline CSO & 49.57 & 0 & 47.50 & 0 & 44.22 & 0 & 42.65 & 0 & 45.99 & 0 \\
\hline CS1 & 49.31 & -0.52 & 46.65 & -1.79 & 43.15 & -2.42 & 41.55 & -2.58 & 45.17 & -1.78 \\
\hline CS2 & 48.88 & -1.39 & 45.22 & -4.80 & 42.44 & -4.03 & 40.10 & -5.98 & 44.16 & -3.97 \\
\hline CS3 & 48.38 & -2.40 & 42.84 & -9.81 & 40.11 & -9.29 & 38.50 & -9.73 & 42.46 & -7.67 \\
\hline Mean & 49.04 & & 45.55 & & 42.48 & & 40.70 & & 44.44 & \\
\hline
\end{tabular}

CS0 $=$ compost without sulphur,$\quad$ CS1 $1=$ compost with $1 \%$ sulphur, $\quad$ CS $2=$ compost with $2 \%$ sulphur, CS3 $=$ compost with $3 \%$ sulphur. 
Roig et al. (2004) found that, the addition of $S$ to composted organic materials led to decrease of the $\mathrm{pH}$ level within the range 6.0-6.3 which was lower than the control treatment. Addition of sulphur an acidic chemical substance could effectively reduce $\mathrm{pH}$ at a relatively lower cost.

\section{- Compost EC (dS $\left.\mathrm{m}^{-1}\right)$}

The presented data in Table (1) point out the compost EC and its relative change "RC" values (\%) in relation with composting period "CP" and different $S$ additives, Compost EC $\left(\mathrm{dSm}^{-1}\right)$ was increased with the CP extended: prolonged increase in EC of composted organic materials could be due to increase the release of different ions such as $\mathrm{Na}, \mathrm{Ca}, \mathrm{Mg}$ and $\mathrm{PO}_{4}$ resulting from the microbial decomposition of easily decomposable materials (Aiad, 2010 and Belal, 2011). El-Nadi et al. (1998) reported that, the high values of EC recorded during the decomposition may be due to increase of released soluble inorganic ions during mineralization process. The EC of the fresh cow manure range formed 2.2 to $4.0 \mathrm{dS} \mathrm{m}^{-1}$ which implied that, the concentration of soluble salts was in the non-phytotoxic range (lannotti et al., 1994). So, all values of $\mathrm{RC}$ for compost $\mathrm{EC}$ with the increase of $\mathrm{CP}$ were positive and become more positive at the end of CP. The increase of compost EC and their positive RC values associated the $\mathrm{CP}$ increase were occurred with different $\mathrm{S}$.

At the same composting period, increasing the elemental additives of $S$ to composted organic materials appeared an increase in compost EC (Table, 1). These findings may be attributed to oxidizing effect of added $S$ on the composted organic materials followed by increase of many mineral and organic compounds released. These findings also were found at different composting period. In this respect Roig et al. (2004) found that a concentration of $0.5 \%$ in sulphur (dry weight basis) and moisture of $40.0 \%$ were proposed as the optimum conditions to decrease the compost $\mathrm{pH}$ by
1.1 units without increasing in EC to levels that may suppose a limitation for agricultural use.

\section{- Organic matter (OM)}

The presented data in Table (1) elucidate that, prolonging composting period in the composted maize stalks was associated by a decrease of compost content of OM (\%). therefore, the $\mathrm{RC}(\%)$ values of OM content as affected by CP were negative. The decrease in OM content may be due to loss of carbon and $\mathrm{CO}_{2}$ via microbial oxidation during the composting process. This also could be due to the great of action of the carbon consumed by the organisms which is converted into $\mathrm{CO}_{2}$ and released to atmosphere Wong et al. (2001). A similar result was also reported by Aiad (2010) and Belal (2011) found similar decrease of composting organic wastes content of $\mathrm{OM}$, where this decrease was related greatly with the source of composted organic wastes and their initial chemical composition.

At the same composting period, the content (\%) of OM in the composted organic materials was decreased with the increase of added S (Table, 1). So, all RC (\%) values of OM content as affected by increase of $S$ additives were negative and become more negative at high application rate of $S$. The found decrease of compost content of OM as a result of $S$ additives could be due to high rate of oxidation resulted from $S$ presence.

\section{- Total nitrogen (TN)}

The data listed in Table (2) reveal that, at the same treatment of elemental $S$, elongation the composting period "CP" occurred by an increase of total $\mathrm{N}(\%)$. For example, the compost content of total $\mathrm{N}$ in the treatment free of $S$ was increased from $1.20 \%$ at zero time of CP to $1.6 \%$ after 60 day of CP. In addition, all RC values of total $\mathrm{N}$ content as affected by composting period were positive and increased with the $\mathrm{CP}$ increase. Aiad (2010) found that, there is an 
increase of total $\mathrm{N}$ with the increase of $\mathrm{CP}$, but the rates of these increases were related with the source of the composted organic materials and activators used. In this respect, Kenawy (2003) and Nasser (2007) obtained a similar result.
In addition, the data in Table (2) clear that, sulphur additives to composted organic materials resulted in an increase in total $\mathrm{N}$ content (\%) of compost particular at the end of composting period with $3 \% \mathrm{~S}$. Gu et al. (2011) indicated that addition of $S$ could increase the concentration of $\mathrm{NH}_{4}-\mathrm{N}$ and reduces loss of nitrogen.

Table (2): Effect of sulphur additives and composting period"CP" (day) on total- N (T-N), $\mathrm{OC}$ content \% and $\mathrm{C} / \mathrm{N}$ ratio in the compost and its $\mathrm{RC} \%$ as affected by sulphur additives

\begin{tabular}{|c|c|c|c|c|c|c|c|}
\hline \multirow{2}{*}{$\begin{array}{l}\text { Composting } \\
\text { period (day) }\end{array}$} & \multirow{2}{*}{$\begin{array}{l}\text { Treatment of } \\
\text { sulphur }\end{array}$} & \multicolumn{2}{|c|}{ T-N } & \multicolumn{2}{|c|}{ OC } & \multicolumn{2}{|c|}{$\begin{array}{l}\mathrm{C} / \mathrm{N} \\
\text { ratio }\end{array}$} \\
\hline & & $\%$ & $\mathrm{RC}$ & $\%$ & $\mathrm{RC}$ & value & $\mathrm{RC}$ \\
\hline \multirow{4}{*}{0} & CSO & 1.20 & 0 & 28.75 & 0 & 23.96 & 0 \\
\hline & CS1 & 1.18 & -1.67 & 28.60 & -0.52 & 24.24 & 1.16 \\
\hline & CS2 & 1.18 & -1.67 & 28.35 & -1.39 & 24.03 & 0.28 \\
\hline & CS3 & 1.17 & -2.50 & 28.06 & -2.4 & 23.98 & 0.10 \\
\hline \multicolumn{2}{|c|}{ Mean } & 1.18 & & 28.44 & & 24.05 & \\
\hline \multirow{4}{*}{20} & CSO & 1.37 & 0 & 27.55 & 0 & 20.11 & 0 \\
\hline & CS1 & 1.44 & 5.11 & 27.06 & -1.78 & 18.79 & -6.56 \\
\hline & CS2 & 1.57 & 14.60 & 26.23 & -4.79 & 16.71 & -16.91 \\
\hline & CS3 & 1.66 & 21.17 & 24.85 & -9.80 & 14.97 & -25.56 \\
\hline \multicolumn{2}{|c|}{ Mean } & 1.51 & & 26.42 & & 19.64 & \\
\hline \multirow{4}{*}{40} & CSO & 1.50 & 0 & 25.65 & 0 & 17.10 & 0 \\
\hline & CS1 & 1.58 & 5.33 & 25.03 & -2.42 & 15.84 & -7.37 \\
\hline & CS2 & 1.62 & 8.00 & 24.62 & -4.02 & 15.20 & -11.11 \\
\hline & CS3 & 1.73 & 15.33 & 23.27 & -9.28 & 13.45 & -21.35 \\
\hline \multicolumn{2}{|c|}{ Mean } & 1.61 & & 24.64 & & 15.40 & \\
\hline \multirow{4}{*}{60} & CSO & 1.60 & 0 & 24.74 & 0 & 15.46 & 0 \\
\hline & CS1 & 1.67 & 4.37 & 24.10 & -2.59 & 14.43 & -6.66 \\
\hline & CS2 & 1.75 & 9.37 & 23.26 & -5.98 & 13.29 & -14.04 \\
\hline & CS3 & 1.81 & 13.13 & 22.33 & -9.74 & 12.34 & -20.18 \\
\hline \multicolumn{2}{|c|}{ Mean } & 1.71 & & 23.61 & & 13.88 & \\
\hline \multirow{4}{*}{ Mean } & CSO & 1.42 & 0 & 26.67 & 0 & 19.16 & 0 \\
\hline & CS1 & 1.47 & 3.52 & 26.20 & -1.78 & 18.32 & -4.35 \\
\hline & CS2 & 1.53 & 7.75 & 25.62 & -3.96 & 17.31 & -9.66 \\
\hline & CS3 & 1.59 & 11.97 & 24.63 & -7.67 & 16.19 & -15.5 \\
\hline
\end{tabular}

$\mathrm{CS} 0=$ compost without sulphur, $\quad \mathrm{CS} 1=$ compost with $1 \%$ sulphur, $\quad$ CS2 $=$ compost with $2 \%$ sulphur, CS3 $=$ compost with $3 \%$ sulphur 


\section{- $\mathbf{C} / \mathbf{N}$ ratio}

$\mathrm{C} / \mathrm{N}$ ratio is considered the main important aspect of composting. Since the microorganisms involves required carbon for growth and energy and nitrogen for protein synthesis. The rate of decomposition is affected by $\mathrm{C} / \mathrm{N}$ ratio. Rapid and efficient composting is achieved by $\mathrm{C} / \mathrm{N}$ ratio between 25.0 and 35.0, lower ratio result in loss of $\mathrm{N}$ as ammonium, while higher ratio can lead to large composting period (Stevenson, 1994).

Regarding the result of $\mathrm{C} / \mathrm{N}$ ratio and their relative change "RC" (\%) affected by composting period and elemental sulphur additives individually or in together, the data in Table (2) show, $\mathrm{C} / \mathrm{N}$ ratio of the composted organic materials were decreased with the increase of both composting period and added $\mathrm{S}$. thus, the lower $\mathrm{C} / \mathrm{N}$ ratio was found at the end of composting period (60 day) in the organic materials treated by $3 \% \mathrm{~S}$. Consequently, its RC \% was negative. This may be ascribed to that, the $\mathrm{C} / \mathrm{N}$ ratio tended to be narrow with time in composting heaps due to gaseous loss of carbon as $\mathrm{CO}_{2}$ while the nitrogen remained more highly bounded in organic combination. These findings also are in agreement with these obtained by Abd ElWahab (1999); Ali et al. (2005); Aiad (2010) and Nasser (2007).

\section{Available macro nutrients contents}

\section{A - Available nitrogen}

The present data in Table (3) reveal an increase of compost content $(\mathrm{mg} / \mathrm{kg})$ of available $\mathrm{N}$ with prolonging the composting period and $S$ additives individually or together. The content of available $\mathrm{N}$ in the compost untreated with $S$ increased from $142 \mathrm{mg} / \mathrm{kg}$ at zero time of CP to $888 \mathrm{mg} / \mathrm{kg}$ at 60 days of $\mathrm{CP}$. Also, this content after 40 day of CP was increased from $650 \mathrm{mg} / \mathrm{kg}$ in the treatment free from $S$ to $802 \mathrm{mg} / \mathrm{kg}$ in the composted organic materials treated by $3 \%$ S. So, all RC (\%) values of compost content of available $\mathrm{N}$ affected by $\mathrm{CP}$ and $\mathrm{S}$ additives were positive and become more positive in the combined treatments of them. This augmentation in the content of available $\mathrm{N}$ may be attributed to decomposition of organic materials, urea addition and biological fixation by compost microorganisms.

Abd El-Wahab and Ahmed (2003) found that, the relative high values of available $-\mathrm{N}$ obtained may be considered as an indication for occurrence the reduction in nitrogen lost during the composting stages which caused by volatilization of ammonium and leaching down of ammonium and nitrate. The factors which led to nitrogen losses are the high temperature, alkaline $\mathrm{pH}$ and forced action.

\section{B - Available phosphorus}

Regarding to the data of effect the CP (day) and $S$ additives (\%) individually or together on the composted organic materials content of available $\mathrm{P}$ as listed in Table (3) may be revealed that exceeding composting period and added $S$ resulted in an increase of organic materials content of available $P$. For example, at the compost untreated with $S$ the content of available $P$ was increased from $675 \mathrm{mg} / \mathrm{kg}$ at zero time of CP to 711 $\mathrm{mg} / \mathrm{kg}$ at the end CP. Also this content of compost at 40 days of $\mathrm{CP}$ was increased from $706 \mathrm{mg} / \mathrm{kg}$ in the compost free from S to $747 \mathrm{mg} / \mathrm{kg}$ in the compost organic materials treated by $3 \% \mathrm{~S}$. In addition, all RC (\%) values of compost content of available $P$ as affected by $C P$ and $S$ additives were positive and there were more positive in the combination treatments of $\mathrm{CP}$ and $\mathrm{S}$.

The linearly increase of available $P$ during composting period may be attributed to the effect on phosphate dissolving microorganisms in compost mineralization, consequently releasing phosphorus in the available form. These results are in harmony with those of Singh and Sharman (2002) and Aiad (2010). 
Table (3): Effect of sulphur additives and composting period "CP" (day) on the compost content $(\mathrm{mg} / \mathrm{kg})$ of available $\mathrm{N}, \mathrm{P}$ and $\mathrm{K}$ and its $\mathrm{RC} \%$ as affected by sulphur additives

\begin{tabular}{|c|c|c|c|c|c|c|c|}
\hline \multirow{2}{*}{$\begin{array}{l}\text { composting } \\
\text { period (day) }\end{array}$} & \multirow{2}{*}{$\begin{array}{c}\text { Treatment of } \\
\text { sulphur }\end{array}$} & \multicolumn{2}{|c|}{$\mathrm{N}$} & \multicolumn{2}{|c|}{ P } & \multicolumn{2}{|c|}{ K } \\
\hline & & $\mathrm{mg} \mathrm{kg}^{-1}$ & $\mathrm{RC}$ & $\mathrm{mg} \mathrm{kg}^{-1}$ & $\mathrm{RC}$ & $\mathrm{mg} \mathrm{kg}^{-1}$ & $\mathrm{RC}$ \\
\hline \multirow{4}{*}{0} & CSO & 142 & 0 & 675 & 0 & 1550 & 0 \\
\hline & CS1 & 145 & 2.11 & 687 & 1.78 & 1596 & 2.97 \\
\hline & CS2 & 148 & 4.23 & 701 & 3.85 & 1644 & 6.06 \\
\hline & CS3 & 150 & 5.63 & 697 & 3.26 & 1688 & 8.90 \\
\hline \multicolumn{2}{|c|}{ Mean } & 146 & & 690 & & 1620 & \\
\hline \multirow{4}{*}{20} & CSO & 370 & 0 & 701 & 0 & 1647 & 0 \\
\hline & CS1 & 410 & 10.81 & 716 & 2.14 & 1819 & 10.44 \\
\hline & CS2 & 425 & 14.86 & 742 & 5.85 & 1819 & 10.44 \\
\hline & CS3 & 435 & 17.57 & 725 & 3.42 & 2090 & 26.90 \\
\hline \multicolumn{2}{|c|}{ Mean } & 410 & & 721 & & 1844 & \\
\hline \multirow{4}{*}{40} & CSO & 650 & 0 & 706 & 0 & 1868 & 0 \\
\hline & CS1 & 710 & 9.23 & 725 & 2.69 & 2016 & 7.92 \\
\hline & CS2 & 750 & 15.38 & 756 & 7.08 & 2114 & 13.17 \\
\hline & CS3 & 802 & 23.38 & 747 & 5.81 & 2188 & 17.13 \\
\hline \multicolumn{2}{|c|}{ Mean } & 728 & & 734 & & 2047 & \\
\hline \multirow{4}{*}{60} & CSO & 888 & 0 & 711 & 0 & 2016 & 0 \\
\hline & CS1 & 905 & 1.91 & 739 & 3.94 & 2041 & 1.24 \\
\hline & CS2 & 945 & 6.42 & 827 & 16.32 & 2114 & 4.86 \\
\hline & CS3 & 1003 & 12.95 & 797 & 12.10 & 2262 & 12.20 \\
\hline \multicolumn{2}{|c|}{ Mean } & 935.25 & & 768 & & 2108 & \\
\hline \multirow{4}{*}{ Mean } & CSO & 512.50 & 0 & 698.25 & 0 & 1770.25 & 0 \\
\hline & CS1 & 542.50 & 5.85 & 716.75 & 2.65 & 1868.00 & 5.52 \\
\hline & CS2 & 567.00 & 10.63 & 756.50 & 8.34 & 1922.75 & 8.61 \\
\hline & CS3 & 597.50 & 16.59 & 741.50 & 6.19 & 2057.00 & 16.20 \\
\hline
\end{tabular}

CS0 $=$ compost without sulphur, $\quad$ CS1 $1=$ compost with $1 \%$ sulphur, CS2 = compost with $2 \%$ sulphur, CS3 $=$ compost with $3 \%$ sulphur

\section{C - Available potassium}

Both the content of available $\mathrm{K}$ and its $\mathrm{RC}(\%)$ in the composted maize stalk as affected by composting period (day) and $S$ in Table (3) denoted that, there are a positive relationship between composted organic materials content of available $\mathrm{K}$ and its $\mathrm{RC}$ values with either of $\mathrm{CP}$ or added $\mathrm{S}$ alone and in together. wherever the content of available $\mathrm{K}$ was increased by $30.06 \%$ compared to the control at 60 day of $\mathrm{CP}$ Also this content at 40 days of $\mathrm{CP}$ increased by $17.13 \%$ in comparison to the control. The increase in the available $\mathrm{K}$ may be attributed to the mineralization process along the period of incubation Similar results were repelled by Singh and Sharman (2002); Kenawy (2003) and Taha (2007). 


\section{D - Available calcium}

The composted maize stalk content $(\mathrm{mg} / \mathrm{kg})$ of available $\mathrm{Ca}$ and its relative change (RC \%) at different composting periods (day) and also as affected by elemental $S$ additives which recorded in Table (4) elucidate that, extending CP induced a slight increase in $\mathrm{Ca}$ availability of the produced compost however the increase of added $S$ resulted in a decrease of the compost content of available $\mathrm{Ca}$. wherever the produced compost content of available $\mathrm{Ca}$ increased by $3.12 \%$ at 60 days. however, a slight inhibition in available $\mathrm{Ca}$ was induced with $S$ additives.

Table (4): Effect of sulphur additives and composting period "CP" (day) on the compost content $(\mathrm{mg} / \mathrm{kg}$ ) of available $\mathrm{Ca}, \mathrm{Mg}$ and $\mathrm{S}$ and its $\mathrm{RC} \%$ as affected by sulphur additives

\begin{tabular}{|c|c|c|c|c|c|c|c|}
\hline \multirow{2}{*}{$\begin{array}{l}\text { composting } \\
\text { period (day) }\end{array}$} & \multirow{2}{*}{$\begin{array}{l}\text { Treatment of } \\
\text { sulphur }\end{array}$} & \multicolumn{2}{|c|}{$\mathrm{Ca}$} & \multicolumn{2}{|c|}{$\mathrm{Mg}$} & \multicolumn{2}{|c|}{$S$} \\
\hline & & $\mathrm{mg} \mathrm{kg}^{-1}$ & $\mathrm{RC}$ & $\mathrm{mg} \mathrm{kg}^{-1}$ & $\mathrm{RC}$ & $\mathrm{mg} \mathrm{kg}^{-1}$ & $\mathrm{RC}$ \\
\hline \multirow{4}{*}{0} & CSO & 673 & 0 & 4449 & 0 & 152 & 0 \\
\hline & CS1 & 670 & -0.45 & 4333 & -2.61 & 8927 & 5773 \\
\hline & CS2 & 660 & -1.93 & 4260 & -4.25 & 17720 & 11558 \\
\hline & CS3 & 611 & -9.21 & 4150 & -6.72 & 27780 & 18176 \\
\hline \multicolumn{2}{|c|}{ Mean } & 653.5 & & 4431 & & 4430.5 & \\
\hline \multirow{4}{*}{20} & CSO & 682 & 0 & 5143 & 0 & 185 & 0 \\
\hline & CS1 & 682 & 0.00 & 4726 & -8.11 & 9970 & 5289 \\
\hline & CS2 & 675 & -1.03 & 4002 & -22.19 & 19890 & 10651 \\
\hline & CS3 & 619 & -9.24 & 3851 & -25.12 & 28850 & 15495 \\
\hline \multicolumn{2}{|c|}{ Mean } & 664.50 & & 4430.50 & & 14724 & \\
\hline \multirow{4}{*}{40} & CSO & 694 & 0 & 5428 & 0 & 253 & 0 \\
\hline & CS1 & 692 & -0.29 & 4749 & -12.51 & 10760 & 4153 \\
\hline & CS2 & 684 & -1.44 & 4743 & -12.62 & 20360 & 7947 \\
\hline & CS3 & 658 & -5.19 & 4527 & -16.60 & 29250 & 11461 \\
\hline \multicolumn{2}{|c|}{ Mean } & 682.00 & & 4861.75 & & 15156 & \\
\hline \multirow{4}{*}{60} & CSO & 694 & 0 & 5913 & 0 & 296 & 0 \\
\hline & CS1 & 694 & 0.00 & 5245 & -11.30 & 10980 & 3609 \\
\hline & CS2 & 693 & -0.14 & 4792 & -18.96 & 20740 & 6907 \\
\hline & CS3 & 649 & -6.48 & 4731 & -19.99 & 29910 & 10005 \\
\hline \multicolumn{2}{|c|}{ Mean } & 682.50 & & 5170.25 & & 15482 & \\
\hline \multirow{4}{*}{ Mean } & CSO & 685.75 & 0 & 5233 & 0 & 222 & 0 \\
\hline & CS1 & 684.50 & -0.18 & 4763 & -9 & 10159 & 4487 \\
\hline & CS2 & 678.00 & -1.13 & 4449 & -15 & 19678 & 8784 \\
\hline & CS3 & 634.25 & -7.51 & 4315 & -18 & 28948 & 12969 \\
\hline
\end{tabular}

CS0 $=$ compost without sulphur, CS1= compost with $1 \%$ sulphur, CS $2=$ compost with $2 \%$ sulphur, CS3 $=$ compost with $3 \%$ sulphur 


\section{E- Available magnesium}

The present data in Table (4) pointed out that available $\mathrm{Mg}$ appeared the same trend of $\mathrm{Ca}$ as affected by $\mathrm{CP}$ and $\mathrm{S}$ additives. wherever it enhanced by $32.91 \%$ at the end of composting period in compared with control. So, on the contrary $S$ additives showed a harmful effect on $\mathrm{Mg}$ availability. The high content of available $\mathrm{Mg}$ was found in the composted organic materials untreated by $S$ at the end of CP. In this respect similar results were obtained by Taha (2007).

\section{F- Available sulphur}

The content $(\mathrm{mg} / \mathrm{kg})$ of available $S$ and its $R C(\%)$ values of composted maize stalk in relation with both $\mathrm{CP}$ and added $\mathrm{S}$ alone or together recorded in Table (4) showed that, increasing both $\mathrm{CP}$ and added augment the composted organic materials content of available $S$ where $S$ content increased by $94.74 \%$ at 60 day of compost compared with the control (zero time).

Also $S$ content after 40 days of composting period was increased by 11461 $\%$ at $3 \% \mathrm{~S}$ additives. This attributed to the higher amount of added sulphur to the compost material. In this respect $\mathrm{Gu}$ et al. (2011) obtained on similar results.

\section{- Available micronutrients content}

Both the content $(\mathrm{mg} / \mathrm{kg})$ of available micronutrients $(\mathrm{Fe}, \mathrm{Zn}, \mathrm{Mn}$ and $\mathrm{Cu}$ ) and its relative change (RC \%) affected by composting period "CP" (day) and elemental sulphur (S) additives in the composted maize stalks were recorded in Table (5). These data display that, the content $(\mathrm{mg} / \mathrm{kg})$ of available determined micronutrients were increased clearly with the increase of both $\mathrm{CP}$ and added $\mathrm{S}$ individually or together, but these increases were become higher in combination treatments. Also, all RC values calculated for the content of available micronutrients in the composted organic materials affected by the studied treatments were positive and appeared high value at the end of $\mathrm{CP}$ with high rate of added $\mathrm{S}$ (3\%). The composted organic materials contents of $\mathrm{Fe}, \mathrm{Zn}, \mathrm{Mn}$ and $\mathrm{Cu}$ in treatments free from $S$ were increased from 296, 52, 318 and $13 \mathrm{mg} / \mathrm{kg}$ at zero time of CP to 403 , 61,518 and $17 \mathrm{mg} / \mathrm{kg}$ at the end of CP $(60$ day), respectively, Also these contents of the same determined micronutrients in the composted organic materials at 40 days of CP were increased from 367, 56, 424 and $16 \mathrm{mg} / \mathrm{kg}$ at zero treatment of elemental $\mathrm{S}$ to $642,74,550$ and $25 \mathrm{mg} / \mathrm{kg}$ in the composted organic materials treated by $3 \% \mathrm{~S}$, respectively. These data also denoted that, according to the composted organic materials content of available micronutrients under study at different CP and added levels of elemental $S$ as individual or in combination takes the order of $\mathrm{Mn}>\mathrm{Fe}>\mathrm{Cu}$ $>\mathrm{Zn}$. On the other hand, the found RC (\%) values in relation with the content of these available micronutrients were widely varied from nutrient to anther and also from the studied treatment to another. This promotion in the extracted available micronutrients induced with extending the period of incubation may be attributed to mineralization processes of the compost organic matter along the period of incubation consequently releasing the organic acids and chelating agents which cause an enhancement in the available micronutrients (Aiad, 2010 and Belal, 2011). These results are in agreement with these obtained by Abd El-Wahab and Ahmed (2003). 
Abou Hussien, et al.,

Table (5): Effect of sulphur additives and composting period (day) on the compost content $(\mathrm{mg} / \mathrm{kg})$ of available micronutrients and its relative changes "RC" (\%) as affected by sulphur additives.

\begin{tabular}{|c|c|c|c|c|c|c|c|c|c|}
\hline \multirow{2}{*}{$\begin{array}{c}\text { Composti } \\
\text { ng } \\
\text { Period } \\
\text { (day) }\end{array}$} & \multirow{2}{*}{$\begin{array}{l}\text { Treatm } \\
\text { ent of } \\
\text { sulphur }\end{array}$} & \multicolumn{2}{|c|}{$\mathrm{Fe}$} & \multicolumn{2}{|c|}{$\mathrm{Zn}$} & \multicolumn{2}{|c|}{$\mathrm{Mn}$} & \multicolumn{2}{|c|}{$\mathrm{Cu}$} \\
\hline & & $\mathrm{mg} \mathrm{kg}^{-1}$ & $\mathrm{RC}$ & $\mathrm{mg}_{1} \mathrm{~kg}$ & $\mathrm{RC}$ & $\mathrm{mg} \mathrm{kg}^{-1}$ & $\mathrm{RC}$ & $\mathrm{mg} \mathrm{kg}_{1}^{-}$ & $\mathrm{RC}$ \\
\hline \multirow{4}{*}{0} & CSO & 296 & 0 & 52 & 0 & 318 & 0 & 13 & 0 \\
\hline & CS1 & 303 & 2.36 & 54 & 3.85 & 318 & 0.00 & 14 & 7.69 \\
\hline & CS2 & 309 & 4.39 & 55 & 5.77 & 320 & 0.63 & 15 & 15.38 \\
\hline & CS3 & 312 & 5.41 & 55 & 5.77 & 321 & 0.94 & 15 & 15.38 \\
\hline \multicolumn{2}{|c|}{ Mean } & 305 & & 54 & & 319 & & 14 & \\
\hline \multirow{4}{*}{20} & CSO & 333 & 0 & 53 & 0 & 437 & 0 & 15 & 0 \\
\hline & CS1 & 349 & 4.80 & 57 & 9.62 & 454 & 3.89 & 17 & 13.33 \\
\hline & CS2 & 407 & 22.22 & 65 & 25.00 & 455 & 4.12 & 23 & 53.33 \\
\hline & CS3 & 591 & 77.48 & 70 & 34.62 & 488 & 11.67 & 24 & 60.00 \\
\hline \multicolumn{2}{|c|}{ Mean } & 420.00 & & 61.00 & & 458.50 & & 19.75 & \\
\hline \multirow{4}{*}{40} & CSO & 367 & 0 & 56 & 0 & 424 & 0 & 16 & 0 \\
\hline & CS1 & 460 & 25.34 & 67 & 19.64 & 512 & 20.75 & 20 & 25.00 \\
\hline & CS2 & 556 & 51.50 & 69 & 23.21 & 516 & 21.70 & 24 & 50.00 \\
\hline & CS3 & 642 & 74.93 & 74 & 32.14 & 550 & 29.72 & 25 & 56.25 \\
\hline \multicolumn{2}{|c|}{ Mean } & 506.25 & & 66.50 & & 500.5 & & 21.25 & \\
\hline \multirow{4}{*}{60} & CSO & 403 & 0 & 61 & 0 & 518 & 0 & 17 & 0 \\
\hline & CS1 & 508 & 26.05 & 66 & 8.20 & 523 & 0.97 & 20 & 17.65 \\
\hline & CS2 & 650 & 61.29 & 69 & 13.11 & 529 & 2.12 & 26 & 52.94 \\
\hline & CS3 & 811 & 101.24 & 72 & 18.03 & 618 & 19.31 & 28 & 64.71 \\
\hline \multicolumn{2}{|c|}{ Mean } & 593.00 & & 67.00 & & 547.00 & & 22.75 & \\
\hline \multirow{4}{*}{ Mean } & CSO & 350 & 0 & 56 & 0 & 424 & 0 & 15 & 0 \\
\hline & CS1 & 405 & 15.80 & 61 & 10.41 & 452 & 6.48 & 18 & 16.39 \\
\hline & CS2 & 481 & 37.38 & 65 & 16.74 & 455 & 7.25 & 22 & 44.26 \\
\hline & CS3 & 589 & 68.41 & 68 & 22.62 & 494 & 16.50 & 23 & 50.82 \\
\hline
\end{tabular}

CS0 $=$ compost without sulphur, $\quad$ CS1 $=$ compost with $1 \%$ sulphur, $\quad$ CS $2=$ compost with $2 \%$ sulphur, CS3 $=$ compost with $3 \%$ sulphur

\section{REFERENCES}

Abd El-Wahab, A. F. M. (1999). Iron- zinc organic wastes interaction and their effect on biological nitrogen fixation in newly reclaimed soils. Ph.D. Thesis, Fac. of Agric. Ain Shames Univ. Egypt.

Abd El-Wahab, A. F. and A. S. Ahmed (2003). Preparation of bioorganic materials for their utilization as soil 
amendment and growth media. Annals Agric. Sci. Ain Shams Univ., Cairo, 48(2): 561-572.

Aiad, N. A. (2010). Application of organic wastes for sustainable of agriculture. Ph.D. Thesis, Fac. of Agric. Menoufia Univ. Egypt.

Ali, Laila K. M., M. H. Abd El Salam and N. R. Habashy (2005). Effect of soil amendment on some properties of calcareous soil and its productivity. Menoufia J. Agric. Res 30 (2): 735-749.

Anwar, M. N., J. U. Sarker, M. Rahman, M. A. Islam and M. Begum (2001). Response of onion to nitrogen, phosphorus, potassium, sulphur and zinc. Bangladesh J. Environ. Sci., 7: 6872.

Belal, E. E. E. (2011). Kineties of humic substances in calcareous soils under organic farming system. Ph. D. Thesis Fac. of Agric. El-Fayoum Univ. Egypt.

Cottenie, A., M. Verloo, L. Kickens, G. Velghe and R. Camerlynck (1982). Chemical analysis of plants and soils. Laboratory of Analytical and Agrochemistry. State University, Ghent Belgium, pp: 63.

El-Nadi, A. H., R. K. Rabie, H. M. Abdel Magid, R. E. A. Sabrah and S. I. Abde Aal (1998). Chemical, physio-chemical and microbiological examination of town refuses compost and chicken manure as organic fertilizers. J. Arid Enviro. 30: 107113.

Forney, C. F., M. A. Jordan, L. CampbellPalmer, S. Fillmore, K. McRae and K. Best (2010). Sulfur fertilization affects onion quality and flavor chemistry during storage. Acta. Hort., 877: 163168.

Gu, W., F. Zhang, P. Xu, Sh. Tang, K. Xie, X. Huang and Q. Huang (2011). Effects of sulphur and Thiobacillus thioparus on cow manure aerobic composting. Bioresource Technology 102: 65296535.

Havlin, J. L., J. D. Beaton, S. L. Tisdale and W. L. Nelson (2004). Soil Fertility and Fertilizers: An introduction to nutrient management. 7th Ed. Pearson Education Inc. Singapore. p 221.

lannotti, D. A., M. E. Grebus, B. L. Toth, L. V. Madden and H. A. J. Hoitik (1994). Oxygen respirometric method to assess stability and maturity of composted municipal solid waste. J. Environ. Qual. 23: 1177-1183.

Kenawy, Mona H. M. (2003). Biochemical studies on some agricultural wastes. Ph.D. Thesis, Fac. of Agric. Cairo Univ. Egypt.

Marwa, A. A. (2007). Evaluation of some amendments in new reclaimed soils. MSc. Thesis, Fac. of Agric. Zagazig Univ. Egypt.

Nasser, M. M. A. (2007). Different source of organic wastes processing and its effect on some soil properties and on the productivity of wheat and maize crops. Ph.D. Thesis, Fac. of Agric. Kafer ElSheikh Univ. Egypt.

Page, A. L., R. H. Miller and D. R. Keeney (1982). Methods of Soil Analysis, Part 2. Chemical and Microbiological properties second Edition. Wisconsin, U.S.A.

Razikordmahalleh, L. (2014). Production of compost with useful microorganisms from sugar cane Bagasse enriched with rock Phosphate, Urea and Sulphur. Journal of Environmental Research and Management, 5(7): 119- 124.

Roig, A., M. L. Cayuela and M. A. SánchezMonedero (2004). The use of elemental sulfur as organic alternative to control $\mathrm{pH}$ during composting of olive mill wastes. Chemosphere, 57: 1099-1105.

Schindler, S. C., M. J. Mitchell, T. J. Scott, R. D. Fuller and C. T. Driscoll (1986). Incorporation of ${ }^{35} \mathrm{~S}$-sulfate into inorganic and organic constituents of two forest soils. Soil Science Society of America Journal. 50: 457-462.

Singh, A. and S. Sharman (2002). Composting of crop residue treatment with microorganisms and subsequent vermin composting. Bioresource Technology. 85: 107-111. 


\section{Abou Hussien, et al.,}

Stevenson, F. J. (1994). Humus Chemistry; Genesis Composition Reaction, $2^{\text {nd }}$ ed. John Wiley. New York.

Strick, J. E. and J. P. Nakas (1984). Calibration of a microbial sulfur technique for use in forest soils. Soil Biology and Biochemistry. 16:289-291.

Strickland, T. C., J. W. Fitzgerald, J. T. Ash and W. T. Swank (1987). Organic sulfur transformations and sulfur pool sizes in soil and litter from a southern Appalachian hardwood forest. Soil Science. 143:453-458.

Taha, M.B. (2007). Recycling of organic wastes for using as amendments. Ph.D. Thesis, Fac. of Agric. Minia Univ. Egypt.

Tejada, M., C. Garcia, J. Gonezalez and L. Hernanedz (2006). Use of organic amendments as astrategy for saline soil remediation: Influence on the physical, chemical and biological properties of soil. Soil Biology and Biochemistry 38: 14131421.

Verma, S. (2013). Effect of compost on soil phosphorus availability. Ph.D. Thesis Fac. of Agriculture University of Adelaide. Australia.

Walker, K. and C. Dawson (2003). Sulphur fertilizer recommendations. Fertilizers Fertilization, 3: 71-89. (In Polish).

Wong, J. W. C., K. F. Mak, N. W. Chan, A. L. Am, M. Fang, L. X. Zhou, Q. T. Wuand and X. D. Liao (2001). Co-composting of soybean residues and leaves in Hong Kong. Bioresource Technology. 76: 99106. 
تأثير إضافات الكبريث على التركيب الكيميائى للكمبوست

الحسينى عبدالغفار أبوحسين ، محمد نجيب السيد فياض ، وائل محمد عبدالرحمن ندا ، محمد خالاد السبد الجزيرى

قسم علوم الاراضى - كلية الزراعة - جامعة المنوفية -شبين الكوم - مصر

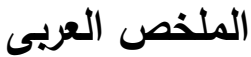

أجري هذا البحث فى صوبة قسم علوم الاراضى - كلية الزراعة - جامعة المنوفية - شبين الكوم سمصر لاراسة تأثير الاضافات المختلفة من الكبريت على خواص الكمبوست الكيميائية ومحتواه من المغذيات الكبرى والصغرى الميسرة عند فترات كمر مختلفة. تم تجهيز أربع كومات من خليط من حطب الذرة الناعم والسماد البلاى من لاصى بنسبة خلط 65 : 35 \% على أساس الوزن الجاف كما أضيف إلى الكومات منشطات كيميائية أخرى وقد تم ترطيب الكومات عند محتوى رطوبى 60 \% من السعة التشبعية للمواد المكموره وقد أجريت عملية التهوية لهذه الكومات كل خمسة عشر يوماً. وقد أخذت عينات من كل كومة بعد صفر و 20 و 40 و 60 يوم من الكمر وندر وقدر لها الخواص الكيميائية وكنلك محتواها من المغذيات الكبرى والصغرى الميسرة.

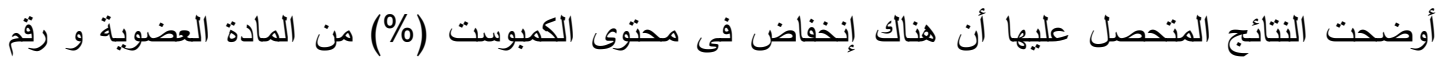
الحموضة مع زيادة المضاف من الكبريت وكذلك مع زيادة زمن الكمر بينما زاد محتوى الكمبوست من النيتروجين والتوصيل الكهربى ولذلك قلت نسب ك : ن بالإضافة إلى ذلك فقد ازداد محتوى الكمبوست من من كل من المغذيات الكبرى الميسره (نبتروجين - فسفور - بوتاسيوم - كالسيوم - مغنسيوم والكبريت) وكذلك المغذيات الصغرى (حديد - زنكك - منجنيز والنحاس) بزيادة المضاف من الكبريت وزيادة فترة الكمر • وتعنى النتائج المتحصل عليها أن إضافات الكبريت إلى المواد العضوية المتخمرة تحسن من خواص وجودة الكمبوست الناتج. 